\title{
3D Strateji Öğretiminin Öğrenme Güçlüğü Olan Öğrencilerin Bilişsel ve Üstbilişsel Stratejileri Kazanmalarına Etkisi ${ }^{1}$
}

\section{The Effect of TWA Strategy Instruction on Students with Learning Disabilities Developing Cognitive and Metacognitive Strategies}

\section{Tahsin Fırat ${ }^{2}$, Cevriye Ergül ${ }^{3}$}

\author{
Anahtar Kelimeler \\ 3D stratejisi \\ strateji öğretimi \\ öğrenme güçlüğü olan \\ öğrenciler \\ üstbilişsel strateji \\ bilişsel strateji
}

\section{Keywords \\ TWA strategy \\ strategy instruction \\ students with learning \\ diabilities \\ metacognitive strategy \\ cognitive strategy}

Başvuru Tarihi/Received

31.10.2019

Kabul Tarihi /Accepted

22.11.2019
Öz

Öğrenme güçlüğü olan öğrencilerin önemli bir çoğunluğu okuduğunu anlama ciddi güçlükler yaşamaktadır. Bu güçlüklerin temel nedenlerinden biri okuduğunu anlamada etkili olan bilişsel ve üstbilişsel becerilerdeki yetersizlikleridir. Bu araştırma, 3D (Okuma Öncesinde Düşün, Okuma Sırasında Düşün ve Okuma Sonrasında Düşün) stratejisinin, öğrenme güçlüğü olan öğrencilerin bilişsel ve üstbilişsel okuma stratejilerini kazanmalarına etkisini incelemek amacıyla yapılmıştır. Araştırma, 6. sınıfa devam eden ve öğrenme güçlüğü tanısı almış üç öğrenciyle gerçekleştirilmiştir. Bu çalışma nitel bir yöntem kullanılarak tasarlanmıştır. Uygulama süreci 3D stratejisi öğretimi için önkoşul becerileri geliştirme ve tartışma, model olma, rehberli uygulamalar ve bağımsız uygulamalar şeklinde sürdürülmüştür. Katılımcıların bilişsel ve üstbilişsel stratejileri kazanıp kazanamadıklarını belirlemek için öğretim öncesinde ve sonrasında, sesli düşünme ve yarı-yapılandırılmış görüşme teknikleri kullanılmıştır. Elde edilen veriler, içerik analizi yapılarak katılımcıların kazandıkları ve kullandıkları stratejiler ortaya çıkarılmıştır. Araştırma sonucunda, 3D stratejisi öğretiminin, katılımcı öğrencilerin okuma öncesi, sırası ve sonrasında bilişsel ve üstbilişsel stratejileri kazanmalarında etkili olduğu belirlenmiştir. Elde edilen sonuçlar, alanyazın ve uygulamalar açısından tartışılmıştır.

\section{Abstract}

The majority of students with learning disabilities have severe difficulties in reading comprehension. One of the main reasons for these difficulties is their deficiency in cognitive and metacognitive skills that are effective in reading comprehension. The aim of this study was to investigate the effect of TWA (Think Before Reading, Think While Reading, and Think After Reading) strategy on developing cognitive and metacognitive reading strategies of students with learning disabilities. The research was carried out with three students who were diagnosed with learning disabilities and who were continuing their education in 6 th grade in secondary schools. The study was designed using a qualitative method. The implementation process has been continued in the form of prerequisite skills development and discussion, modeling, guided practices and independent practices for the teaching of TWA strategy. The techniques think-aloud and semi-structured interview were used before and after teaching to determine students' developing cognitive and metacognitive strategies. The data obtained were analyzed by content analysis method and the strategies that the participants developed and used were revealed. As a result of the research, it was determined that the teaching of TWA strategy was effective in developing cognitive and metacognitive strategies before, while and after reading. The results were discussed in terms of future research and practice.

\footnotetext{
${ }^{1}$ Bu makale, Tahsin Fırat'ın Ankara Üniversitesi Eğitim Bilimleri Enstitüsü’nde Doç. Dr. Cevriye Ergül danışmanlığında hazırladığı doktora tezinden üretilmiştir.

${ }^{2}$ Adıyaman Üniversitesi, Eğitim Fakültesi, Özel Eğitim Bölümü, Adıyaman, TÜRKiYE; https://orcid.org/0000-0002-3577-7907

${ }^{3}$ Ankara Üniversitesi, Eğitim Bilimleri Fakültesi, Özel Eğitim Bölümü, Ankara, TÜRKiYE; https://orcid.org/0000-0001-6793-6469
} 
Extended Abstract

\section{Introduction}

The use of metacognitive strategies requires readers to remember the old information about the subject read, to become aware of the purpose of reading, to identify important information, to understand their comprehension, to self-question and correct themselves when they fail to understand. In this respect, one of the strategies used to improve students with learning disabilities' comprehension skills is TWA (Think Before Reading, Think While Reading, and Think After Reading) strategy applied by using the instructional steps of the self-regulation strategy development approach (SRSD). TWA created by Mason (2002) is a strategy that is effective in the development of skills of students with learning disabilities to comprehend informative texts. Considering that researches conducted in Turkey, it is noteworthy that the studies based on the strategy instruction for developing reading comprehension skills of students with learning disabilities have been performed in a very limited number. However, the students with learning disabilities in Turkey suffer from severe problems in terms of comprehending what they read. Therefore, teaching the use of strategy in these children is extremely important in terms of improving their reading comprehension performance. In this sense, the aim of this study is to examine the effect of TWA strategy instruction on the development of cognitive and metacognitive strategies.

\section{Method}

The research was carried out with 3 students who were diagnosed with learning disabilities and who were continuing their education in 6 th grade in secondary schools. The data of the study were collected by using the techniques think-aloud and semistructured interview. Content analysis technique was used in data analysis. In this respect, the strategies used by the students were evaluated by two evaluators who were informed about metacognitive strategies. The codes and categories obtained from the independent coding by two evaluators were compared. The reliability coefficient of the coding in this process was calculated as .90. In addition, at least one sample was selected from the videos of the starting level, modelling of TWA strategy instruction, guided practices and independent practices sessions for each subject to be watched by two observers who were experts in reading comprehension. Then, at least $33.33 \%$ of the records were made to watch for each subject. According to this, the reliability of implementation of modelling, guided practices and independent practices sessions was found between $93.75 \%$ and $100 \%$ for each student.

\section{Result and Discussion}

The techniques think-aloud and semi-structured interview were used before and after teaching to determine students' developing cognitive and metacognitive strategies. The findings and discussion below are presented.

\section{Findings with Think-Aloud Technique}

Through think-aloud for the cognitive and metacognitive strategy use of the students, two findings were obtained before and after instruction.

Findings before instruction. In the think-aloud method that was used to evaluate the cognitive and metacognitive strategies of the students before the instruction, it was determined that all three subjects did not make any effort to understand the text before reading, started to read directly and read continuously until the end of the text. At the same time, it was found that they did not use any strategy to understand the text and spend very little time to comprehend the text.

Findings after instruction. The teaching of the TWA strategy has increased the diversity of the pre and post-reading strategies that subjects use to comprehend the text. For this reason, it can be said that TWA strategy instruction is effective in development of cognitive and metacognitive strategies by students with learning disabilities.

\section{Findings with Semi-Structured Interview Techniques}

Through semi-structured interviews for the cognitive and metacognitive strategy knowledge of the students, two findings were obtained before and after instruction.

Findings before instruction. The first subject was found to have limited levels of cognitive and metacognitive strategies at all stages of reading. For example, in the semi-structured interview, the subject used expressions such as "... I look at the picture to better understand the text ...". It was found that the second subject had a limited level of cognitive and metacognitive strategies during and after reading stages, and did not use any strategy before reading. In the semi-structured interview, the subject used expressions such as “... I read the text two times to better understand it ...". It was found that the third subject had a limited level of cognitive and metacognitive strategies during reading and after reading stages, and did not use any strategy before reading. In the semi-structured interview, the subject used expressions such as “... I reread the places I did not understand two times to better understand it ...".

Findings after instruction. The cognitive and metacognitive strategies used by the first subject were significantly increased and varied in all reading stages. In the semi-structured interview, the subject used expressions as "... I think about what I know about the text I will read to better understand it ...". The cognitive and metacognitive strategies used by the second subject were 
significantly increased and varied in all the reading stages. In the semi-structured interview, the subject used expressions such as "... I previously read the the first paragraph to better understand the text ...". The cognitive and metacognitive strategies used by the third subject were significantly increased and varied in all the reading stages. In the semi-structured interview, the subject used expressions such as "... I think about what I want to learn to better understand the text ...". As a result, TWA strategy teaching increased the diversity of strategies used by all three subjects according to pre-instruction. Therefore, it can be stated that TWA strategy teaching is effective in the development of cognitive and metacognitive strategies for students with learning disabilities. 
Giriş

Okuduğunu anlama becerisi temel akademik bir beceri olup, okul başarısı üzerinde önemli bir role sahiptir (Crabtree, AlberMorgon, \& Konrad, 2010). Diğer taraftan bu becerinin başarılı bir şekilde ortaya konulması, pek çok bilişsel sürecin birlikte yürütülmesine ve uyumuna bağlıdır (Kendeou, Van den Broek, Helder, \& Karlsson, 2014; Van den Broek, \& Espin, 2012). Okuduğunu anlamanın etkili bir şekilde gerçekleşebilmesi için öğrencilerin okumaya karşı güdülenmeleri (Guthrie \& Wigfield, 2000; Logan, Medford, \& Hughes, 2011), akıcı okumaları (Padeliadu \& Antoniou, 2014; Palincsar \& Brown, 1984), metin yapısı bilgisine sahip olmaları (Duke, Pearson, Strachan, \& Billman, 2011; Gersten, Fuchs, Williams, \& Baker, 2001) ve okuduklarını önceki bilgileri ile ilişkilendirmeleri (Meneghetti, Carretti, \& De Beni, 2006; Pardo, 2004) gerekmektedir. Bununla birlikte, okuma öncesi, sırası ve sonrasında kendini düzenleme stratejilerini kullanmaları ve önceki bilgileri aktifleştirme, okuma için amaç oluşturma, çıkarımda bulunma, görselleştirme ve özetleme gibi bilişsel stratejileri kullanmaları önemlidir (Bender, 2002; Dabarera, Renandya, \& Zhang, 2014; Paris \& Myers, 1981). Öğrencilerin bu stratejileri "niçin?”, "ne zaman?" ve "nasıl?” kullanacaklarını bilmeleri (Harvey \& Goudvis, 2013; Pintrich, 2002) ve bunları izleme ve değerlendirmelerine yönelik bir dizi üstbilişsel stratejiyi de kullanmaları gerekmektedir (Carrel, 1998; Dabarera ve diğ., 2014; Mason, Meadan, Hedin, \& Corso, 2006; Paris \& Myers, 1981; Pressley \& Gaskins, 2006).

Bireyin düşünceleri hakkında düşünmesi anlamına gelen üstbiliş (Flavell, 1979; Kuhn \& Dean, 2004), günümüzde en çok vurgu yapılan ve araştırılan konuların başında gelmektedir. Özellikle okuduğunu anlama ile ilişkisi alanyazında sıklıkla yer almakta, okuduğunu anlamanın geliştirilmesi çalışmaları çoğunlukla üstbilişsel strateji öğretimi üzerine temellendirilmektedir (Cummins, Stewart, \& Block, 2005). Okuyucuların okudukları metnin anlamını oluşturmaları için ne tür stratejiler kullanmaları gerektiği ve bu stratejileri farklı amaçlarla ne zaman ve nasıl kullanacakları üstbiliş tarafından belirlenmektedir (Al-Shaye, 2002). Bu yönüyle üstbilişin anlama ile ilgili bilişsel süreçlerin yerine getirilip getirilmediğini değerlendirdiğini, amaçlı ve bilinçli bir şekilde kontrol ettiğini ve yürütülmesini sağladığını söylemek mümkündür (Gersten ve diğ., 2001). Bu açıdan üstbiliş, ilgili bilişsel süreçler ve stratejilerle birlikte ele alınmaktadır.

Bilişsel stratejiler, kişinin bir amaca ulaşmasını ve öğrenmeyi sağlarken, üstbilişsel stratejiler kişinin bu süreçte kendini izlemesini, test etmesini ve değerlendirmesini içerir (Coppins, 2008; Doğanay-Bilgi, 2009). Diğer bir ifadeyle bilişsel stratejiler anlamayı sağlayan adımlar olarak ifade edildiğinde, üstbilişsel stratejiler bu adımların ne kadar doğru, etkili ve amaca uygun olduğunu izlenmesini ve yeniden düzenlenmesini içerir (Karbalaei, 2011). Dolayısıyla üstbilişsel stratejiler, bilişsel süreçler üzerinde gözlemci ve kontrol edici bir rol oynar ve anlamaya yönelik süreçlerin etkili bir şekilde gerçekleşmesini sağlar.

Üstbilişsel stratejilerin kullanımı, okuyucunun okunan konu ile ilgili eski bilgilerini hatırlamasını, okuma amacının farkına varmasını, önemli bilgileri belirlemesini, anlamalarını izlemesini, kendini sorgulamasını ve anlama ile ilgili başarısızık yaşadığında kendini düzeltmesini gerektirmektedir (Galloway, 2003). Ayrıca, öğrencilerde içsel bir dil oluşturarak öğrencinin metinle etkileşime girmesini ve bağlantılar kurmasını sağlamaktadır (Bender, 2002). Bu bağlamda üstbilişsel stratejileri kullanan okuyucuların metne daha amaçlı yaklaştıkları ve eleştirel düşündükleri söylenebilir (Rock, 2016). Okuma sürecine aktif katılımı sağlayan bu stratejiler, başarılı okuyucuların karakteristik özelliği olarak ifade edilmektedir (Dermitzaki, Andreou, \& Paraskeva, 2008; Hughes \& ParkerKatz, 2013; Houtveen \& Van de Grift, 2007; Moya, 1993; Root-Littlefield, 2011). Bu yüzden üstbilişsel becerilere sahip öğrenciler daha etkili okuma yapan öğrencilerdir (Swanson \& De La Paz, 1998).

Diğer taraftan öğrenme güçlüğü olan öğrencilerin büyük bir çoğunluğunun okuduğunu anlama konusunda ileri düzeyde güçlükler yaşadıkları ve akranlarından önemli ölçüde geri oldukları ifade edilmektedir (Gersten ve diğ., 2001; Kennedy \& Deshler, 2010). Öğrenme güçlüğü olan öğrencilerin bilişsel ve üstbilişsel stratejileri kullanmada önemli güçlükler yaşadıkları (Anastasiou \& Griva, 2009; Botsas, 2017; Wigent, 2013) ve bu stratejileri etkin bir şekilde kullanamamalarının, anlamalarını olumsuz etkiyen temel neden olduğu belirtilmektedir (Gaddy, 2004; Hagaman, Luschen, \& Reid, 2010; Mastropieri, Scruggs, \& Graetz, 2003; Swanson \& Vaughn, 2010). Öğrenme güçlüğü olan öğrencilerin okumak için amaç oluşturamadıkları, anlamalarını izleyemedikleri, metnin zorluk düzeyine göre okumalarını düzenleyemedikleri ve çıkarım yapamadıkları belirtilmektedir (Baker \& Brown, 1984; Sencibaugh, 2007). Başarılı okuyucular ve öğrenme güçlüğü yaşayan öğrencilerin karşılaştırıldığı bir çalışmada Wigent (2013), başarılı okuyucuların daha bilinçli ve amaçı olarak okuma stratejilerini kullandıklarını, ana fikir ve ayrıntılarını hatırlamak için strateji çeşitliliği ve zenginliğine sahip olduklarını, buna karşın öğrenme güçlüğü olan öğrencilerin okumaya yönelik hazırlık planlarının olmadığını ve okuma stratejilerini kullanmada genel anlamda amaçlı olmadıklarını belirlemiştir. Botsas (2017) ise öğrenme güçlüğü olan öğrencilerin sınırlı düzeyde üstbilişsel stratejiye sahip olduğunu, bu stratejileri az ve yüzeysel kullanan pasif okuyucular olduğunu, buna karşın başarılı okuyucuların okudukları metni anlamak için birçok stratejiyi etkili olarak kullandıklarını belirlemiştir. Bu bağlamda üstbilişsel strateji kullanımının başarılı okuyucular ile zayıf okuyucuları özellikle öğrenme güçlüğü yaşayan öğrencileri ayıran temel özelliklerden biri olduğu ifade edilebilmektedir. Diğer taraftan bu öğrencilere yönelik yapılan diğer çalışmalarda öğrenme güçlüğü olan öğrencilerin üstbilişsel stratejileri öğrenebildikleri ve üstbilişsel strateji öğretiminin öğrencilerin okuduğunu anlama becerilerinin gelişmesinde önemli etkisinin olduğu belirtilmiştir (Alqahtani, 2016; Berkeley, Mastropieri, \& Scruggs, 2011; Bosson ve diğ., 2010). Ayrıca, öğrenme güçlüğü olan öğrencilerin anlama becerilerini geliştirmeye yönelik yapılmış müdahale çalışmalarının değerlendirildiği araştırmalar incelendiğinde, strateji öğretiminin okuduğunu anlamaya olumlu etkilerinin olduğu (Edmonds ve diğ., 2009; Forness, Kavale, Blum, \& Lloyd, 1997; Gajria, Jitendra, Sood, \& Sacks 2007; Gersten ve diğ., 2001; Kim, Linan-Thompson, \& Misquitta, 2012; Mastropieri ve diğ., 2003; Scammacca ve diğ., 2007; Talbott, Lloyd, \& Tankersley, 1994; Vaughn, Gersten, \& Chard, 2000) ve bu çalışmalardan bazılarında ise bilişsel ve üstbilişsel strateji öğretiminin, okuduğunu anlama becerilerinin gelişimini etkileyen en önemli faktör olduğu belirtilmiştir (Forness ve diğ., 1997; 
Gajria ve diğ., 2007; Gersten ve diğ., 2001; Kim ve diğ., 2012; Swanson, 1999). Bu nedenle, öğrenme güçlüğü olan öğrencilere üstbilişsel strateji öğretimi bu öğrencilerin okuduğunu anlama becerilerinin gelişmesi açısından büyük önem arz etmektedir. Son yıllarda öğrenme güçlüğü olan öğrencilerin okuduğunu anlama becerilerini geliştirmek amacıyla kullanılan stratejilerden birisi TWA (Think Before Reading, Think While Reading, Think After Reading) stratejisidir.

\section{TWA Stratejisi}

Mason (2002) tarafından oluşturulan bu strateji öğrenme güçlüğü olan öğrencilerin bilgi verici metinleri anlama becerilerinin gelişiminde etkili ve öğrencilerin okuma süresince düşünmesini gerektiren bir stratejidir (Mason, Meadan-Kaplansky, Hedin, \& Taft, 2013; Merson, 2016). TWA stratejisi öğrencinin okuma öncesinde, yazarın amacını, kendisinin ne bildiğini ve ne öğrenmek istediğini düşünmesini (Think Before Reading: Okumadan Önce Düşün); okuma sırasında okuma hızını, önceki bilgilerini, tekrar okuması gereken bölümleri (Think While Reading: Okuma Sırasında Düşün) ve okuma sonrasında ise anafikri, özet bilgileri ve ne öğrendiğini düşünmesini (Think After Reading: Okuma Sonrasında Düşün) gerektirmektedir (Mason, Dunn-Davison, Hammer, Miller, \& Glutting, 2012a). TWA stratejisi öğrencinin okuma öncesinde yazarın amacı, kendisinin ne bildiği ve ne öğrenmek istediği hakkında düşünmesini hedefler. Bu adımlarla öğrenci okumaya yönelik amaçlı yaklaşır, amaç oluşturur ve geçmiş bilgilerini harekete geçirir. Okuma sırasında ise öğrencinin okuma hızı, önceki bilgileri ve tekrar okuması gereken bölümler hakkında düşünmesi hedeflenir. Böylelikle, öğrenci okuma hızını kontrol eder, okuduğunu anlayıp anlamadığını izler ve daha önceki bilgileri ile metindeki bilgiler arasında bağlantı kurarak benzerlikler ve farklılıkları ortaya koyar. TWA stratejisi okuma sonrasında da öğrencinin anafikir, özet bilgiler ve ne öğrendiği hakkında düşünmesini hedefler (Mason ve diğ., 2012a). Okuma sonrasındaki bu adımlar ise öğrencinin metinde verilmek istenen ana mesajı bulmasını, gerekli ve gereksiz bilgileri birbirlerinden ayırt etmesini ve anladıklarını kendi ifadesiyle anlatmasını sağlar.

TWA stratejisinin öğrencilerin okuduğunu anlama becerilerinin gelişiminde etkili olduğunu gösteren birçok araştırmaya rastlamak mümkündür (Howorth, Lopata, Thomeer, \& Rodgers, 2016; Johnson, Reid, \& Mason 2011; Mason, 2004; Mason ve diğ., 2006; Mason ve diğ., 2012a; Mason ve diğ., 2013; Mason, Meadan, Hedin, \& Cramer, 2012b; Rogevich \& Perin, 2008). Bu araştırmaların tümü TWA'nın okuduğunu anlamakta güçlük yaşayan öğrencilerin anlama becerilerini geliştirdiğini göstermiştir. Ayrıca bu çalışmaların bir kısmında incelendiği gibi TWA strateji öğretimi öğrencilerin bilişsel ve üstbilişsel stratejileri kazanmalarında da etkili olmaktadır (Johnson ve diğ., 2011; Mason ve diğ., 2012b; Mason ve diğ., 2013; Roohani \& Asiabani, 2015). Örneğin, Johnson ve diğerleri (2011), TWA stratejisinin dikkat eksikliği ve hiperaktivite bozukluğu olan üç lise öğrencisinin okuduğunu anlama becerine etkisini araştırmışlardır. Araştırma sonucunda TWA stratejisinin araştırmaya katılan üç öğrencinin de metnin ana fikrini ve detaylarını hatırlamalarında etkili olduğu belirlenmiştir. Katılımcıların anlama becerilerinin gelişmesinde, kendilerini izleme ve amaç oluşturma gibi üstbilişsel becerileri kazanmalarının önemli rol oynadığı belirtilmiştir. Benzer olarak, Hedin, Mason ve Gaffney (2011) okuduğunu anlama performansları düşük ve dikkat problemleri olan dördüncü ve beşinci sınıfta öğrenim görmekte olan iki öğrenci ile yaptıkları çalışmada TWA stratejisini kullanmışlardır. Haftada 30 dakikalık bir oturum ile 14 hafta devam eden bir uygulama sonucunda verilen TWA stratejisi öğretiminin öğrencilerin kendilerini yönetme ve anlamalarını izleme becerilerini geliştirdiği belirlenmiştir.

\section{Mevcut Araştırma}

Türkiye'de yapılan araştırmalar incelendiğinde ise öğrenme güçlüğü olan öğrencilerin okuduğunu anlama becerilerinin geliştirilmesine yönelik strateji öğretimini temel alan çalışmaların oldukça sınırlı olduğu dikkati çekmektedir. Oysaki araştırmalar, Türkiye'de de öğrenme güçlüğü olan öğrenciler okuduğunu anlamada ciddi problemler yaşadığını ve sınıf düzeyinin çok gerisinde bir performans sergilediklerini göstermektedir (Arabacı, 2017; Delimehmet-Dada \& Ergül, 2020; Görgün \& Melekoğlu, 2019; Sanır, 2017). Bunun en önemli nedenlerinden birisi de strateji kullanmalarındaki yetersizlikleridir (Baydık, 2011; Mastropieri ve diğ., 2003; Sanır, 2017; Swanson \& Vaughn, 2010). Örneğin, Uçar-Rasmussen ve Cora-İnce (2017) yaptıkları çalışmada öğrenme güçlüğü olan öğrencilerin okuduğunu anlama ile tahminde bulunma, zihninde canlandırma, ön bilgilerle ilişkilendirme, izleme ve düzeltme gibi üstbilişsel stratejileri kullanma konusunda güçlük yaşadıklarını belirlemiştir. Diğer taraftan araştırmada uygulanan üstbilişsel strateji öğretimi ile öğrenme güçlüğü olan öğrencilerin okuduğunu anlama becerilerinde önemli gelişmeler olduğunu tespit edilmiştir. Bu kapsamda, bu çalışma TWA stratejisinin, öğrenme güçlüğü olan öğrencilerin bilişsel ve üstbilişsel okuma stratejilerini kazanmalarında etkisini incelemek amacıyla yapılmıştır. Bu öğrencilere yönelik strateji öğretimi yapılmasının okuduğunu anlama performanslarının artırılması açısından son derece önemli olduğu ve bu anlamda araştırmanın alana önemli katkı sağlayacağı düşünülmektedir. TWA stratejisinin ve adımlarının Türkçe olarak anlaşılması için mevcut çalışmada 3D (Okuma Öncesi Düşün, Okuma Sırasında Düşün ve Okuma Sonrası Düşün) şeklinde bir kısaltma kullanılmıştır.

\section{YÖNTEM}

\section{Araştırmanın Modeli}

Bu çalışma nitel bir yöntem kullanılarak tasarlanmıştır. Bu yönüyle çalışma, öğrencilerin müdahale öncesinde ve sonrasında sürece ilişkin görüşleri detaylı bir şekilde alındığından ve sesli düşünme tekniği ile geliştirdikleri stratejiler ortaya çıkarıldığından bir özel durum çalışmasıdır. 


\section{Katılımcılar}

Türkiye'nin güneydoğusunda bir şehirdeki ilı Milli Eğitim Müdürlüğü’ne bağlı ortaokullarda öğrenimlerine devam eden öğrenme güçlüğü tanısı almış 3 öğrenci ile gerçekleştirilmiştir. Katılımcı öğrencilerin seçiminde aşağıdaki ölçütler göz önünde bulundurulmuştur.

a) Altıncı sınıf öğrencisi olma

b) Öğrenme güçlüğü tanısı almış olma

c) Sınıf düzeyine uygun bir metni en az \% 90 oranında doğru okuyabilme (Lerner, 2000; Mercer \& Mercer, 2005)

d) Sınıf düzeyinde seçilen metni hecelemeden okuyabilme

e) Okudukları bilgi verici metinlerden hazırlanan 13 okuduğunu anlama sorusunun en az 2'sine en fazla 6'sına doğru cevap verme

Katılımcıların belirlenmesi iki aşamada gerçekleştirilmiştir. Illk aşamada öğrencilerin okuma doğruluğu ve okuma hızları, ikinci aşamada ise doğruluk ve hız ölçütlerini sağlayan (metni en az \%90 oranında doğru ve hecelemeden okuyabilen) aday katılımcıların okuduğunu anlama becerileri değerlendirilmiştir. Değerlendirmeler sonucunda seçilme ölçütlerini sağlayan üç öğrenci belirlenmiştir. Bu öğrencilerin araştırmaya katılmaları için öncelikle okul ve ailelerden gerekli izinler alınmıştır. Ayrıca öğrencilerinde araştırmaya dahil olma noktasında istekli olmaları göz önünde bulundurulmuştur. Katılımcılara ait özellikler aşağıda verilmiştir.

Araştırmaya katılan birinci katılımcı, 11 yaş 7 aylık, 6. sınıfa devam eden bir kız öğrencidir. Öğrenme güçlüğü tanısı bulunmaktadır. Alt sosyo-ekonomik düzey (SED) bir çevrede yer alan bir okulda öğrenim gören katılımcı, okumada ve matematikte destek eğitim almaktadır. Katılımcının anne ve babası lise mezunudur. Rehberlik servisi ve aile ile yapılan görüşmelerde ailenin çocuğu desteklediği ve bu çalışmaya dahil edilmesi hususunda oldukça istekli oldukları belirlenmiştir. Katılımcıların belirleme sürecinde yapılan değerlendirmede kendisine verilen metni hecelemeden, dakikada 90 sözcüğü doğru ve \%95 oranında doğru okuyarak ve okuduğunu anlama becerilerini ölçmek amacıyla okutulan iki metinde yer alan 13 anlama sorusunun ortalama beşine doğru cevap vererek çalışmaya katılım ölçütlerini karşılamıştır.

İkinci katılımcı, 11 yaş 6 aylık, 6. sınıfa devam eden bir erkek öğrencidir. Alt SED bir çevrede yer alan bir okulda öğrenim gören katılımcı, okumada ve matematikte destek eğitim almaktadır. Katılımcının annesi ortaokul ve babası lise mezunudur. Rehberlik servisi ve aile ile yapılan görüşmelerde ailenin çocuğunu desteklediği ve bu çalışmaya dahil edilmesi hususunda istekli oldukları belirlenmiştir. Katılımcı belirleme sürecinde yapılan değerlendirmede kendisine verilen metni hecelemeden, dakikada 85 sözcüğü doğru ve \%95 oranında doğru okuyarak ve okuduğunu anlama becerilerini ölçmek amacıyla okutulan iki metinde yer alan 13 anlama sorusunun ortalama dördüne doğru cevap vererek çalışmaya katılım ölçütlerini karşılamıştır.

Üçüncü katılımcı ise 11 yaş 8 aylık, 6. sınıfa devam eden bir kız öğrencidir. Öğrenme güçlüğü tanısı bulunmaktadır ve alt SED bir çevrede yer alan bir okulda öğrenim görmektedir. Okumada ve matematikte destek eğitim alan katılımcının annesi ilkokulu tamamlayamamış, babası ise lise mezunudur. Rehberlik servisi ve aile ile yapılan görüşmelerde ailenin çocuğunu desteklemekte yetersiz oldukları belirlenmiştir. Diğer taraftan aile, katılımcının bu çalışmaya dahil edilmesinde istekli davranmıştır. Katılımcı belirleme sürecinde yapılan değerlendirmede kendisine verilen metni hecelemeden, dakikada 80 sözcüğü doğru ve \%95 oranında doğru okuyarak ve okuduğunu anlama becerilerini ölçmek amacıyla okutulan iki metinde yer alan 13 anlama sorusunun ortalama dördüne doğru cevap vererek çalışmaya katılım ölçütlerini karşılamıştır.

\section{Verilerin Toplanması}

Öğrencilerin öğretim öncesinde ve sonrasında, okuma sürecinde kullandıkları bilişsel ve üstbilişsel stratejiler sesli düşünme ve yarı-yapılandırılmış görüşme teknikleri kullanılarak belirlenmiştir.

\section{Sesli Düşünme Tekniği}

Yaygın olarak kullanılan bir teknik olan sesli düşünmede (Afflerbach, 2000; Pressley \& Afflerbach, 1995) öğrenciden okurken ne yaptığına yönelik zihninden geçenleri ifade etmesi istenir ve söyledikleri kaydedilir (Van den Haak, Jong de, \& Schellens, 2003). Bu araştırmada sesli düşünme yoluyla veri toplama beş önemli adımda gerçekleştirilmiştir (Someren, Barnard, \& Sendberg, 1994). İlk olarak veri toplamaya uygun ve katılımcıların kendini rahat ve güvende hissedebileceği bir ortam belirlenmiştir. Ortamın ışık ve ıSı açısından uygun ve gürültüden uzak olmasına dikkat edilmiştir. Öğrencinin yapılan çalışmaya odaklanmasını engelleyecek dikkat çekici uyaranlar uzaklaştırılmıştır. İkinci olarak, katılımcılar sesli düşünme konusunda uygulama öncesinde bilgilendirilmişlerdir. Sesli düşünmenin, metni okurken akıllarına gelen şeyleri sesli olarak söylemelerini gerektirdiği belirtilmiştir. Üçüncü aşamada öğrencilerin sesli düşünmede pratiklik kazanmaları için alıştırma yapılmıştır. Bu amaçla asıl çalışmada kullanılan metne benzer başka bir metin kullanılmış ve katılımcıların sesli düşünme sürecine alışmaları sağlanmıştır. Sonraki aşama katılımcıların metin üzerinde sesli düşünme tekniğini kullandığı uygulama olmuştur. Araştırmacılar, katılımcıları sesli düşünme süreci boyunca izlemiş ve katılımcı konuşmaya ara verdiğinde süreci devam ettirmesi amacıyla uyarmıştır. Son aşama ise katılımcıların tüm sesli düşünme sürecinin ses kayıt cihazlarıyla kaydedilmesi olmuştur. İşleyişin doğru olarak uygulanıp uygulanmadığını kontrol etmek için bilgilendirme ve alıştırma aşamaları da kaydedilmiştir.

Sesli düşünme tekniği ile gerçekleştirilen uygulamada katılımcılar öğretim öncesinde ve sonrasında farklı metinler kullanılarak değerlendirilmişlerdir. Metinlerin belirlenmesi sürecinde öncelikle benzer özelliklere sahip dört metin seçilmiştir. Doğanay-Bilgi 
(2009) tarafından hazırlanmış bilgi verici metinler 5., 6., 7., ve 8. sınıf düzeyinde, 350 (+/- 20) kelimeden oluşmakta ve bir hayvanı tanıtmaktadır. Seçilen bu metinler beş alan uzmanı tarafından değerlendirilmiş, yapılan değerlendirme sonucunda bu tekniğin kullanımına uygun ve orta güçlükte benzer özelliklere sahip en uygun iki metin belirlenmiştir. Bu metinlerden seçkisiz seçilen biri öğretim öncesi, diğeri ise öğretim sonrası değerlendirmede kullanılmıştır.

\section{Yarı-yapılandırılmış Görüşme Tekniği}

Katılımcıların okuduğunu anlamaya yönelik kullandıkları bilişsel ve üstbilişsel stratejileri belirlemek amacıyla yarı yapılandırılmış görüşme tekniği kullanılmıştır. Bu kapsamda araştırmacılar tarafından Strateji Bilgisine ilişkin Görüşme Formu hazırlanmıştır. Bu formda strateji kullanımı konusunda katılımcılardan ayrıntılı yanıtlar almak amacıyla araştırmacılar tarafından sorulacak sorular yer almıştır. Görüşmede katılımcılara metni daha iyi anlamak için: "(1) Okuma öncesinde metni daha iyi anlamak için ne yaparsın?", (2) "Okuma sırasında metni daha iyi anlamak için ne yaparsın?" ve (3) "Okuma sonrasında metni daha iyi anlamak için ne yaparsın?" soruları sorulmuştur. Yanıtları detaylandırmak için sorular çeşitlendirilmiş ve uyarlanmıştır. Öğretim öncesi ve sonrası yapılan görüşme oturumları ses kayıt cihazı ile kayıt altına alınmıştır.

\section{Sosyal Geçerlilik Formu}

3D stratejisi öğretiminin etkililiği ve işlevselliğini ortaya koymak için gerekli olan sosyal geçerlilik verisi; katılımcı öğrenciler, sıra arkadaşları ve Türkçe öğretmenleri için geliştirilen Sosyal Geçerlik Veri Toplama Formlarına verilen cevaplardan elde edilmiştir.

Bu formlarda katılımcı öğrencilere yönelik yönelik 4 soru bulunmaktadır. Bu sorular: (1) 3D stratejisini öğrenme sürecini beğenip beğenmediği, (2) 3D stratejisinin kendilerini daha iyi bir okuyucu yapıp yapmadığı, (3) bu stratejiyi okuma sürecinde uygulamanın kolay olup olmadığı ve (4) sonraki okumalarında uygulayıp uygulamayacaklarına yönelik düşüncelerini elde etmek için hazırlanmıştır. Sıra arkadaşına yönelik üç soru bulunmaktadır. Bu sorular, (1) sıra arkadaşının 3D stratejisiyle gerçekleştirilen öğrenme sürecinin katılımcı öğrencinin anlama becerisinin gelişimine, (2) derse katılımına ve (3) özgüvenine etkisinin olup olmadı̆̆ına yönelik düşüncelerini elde etmek için hazırlanmıştır. Öğretmene yönelik üç soru sorulmuştur. Bu sorular, (1) Türkçe öğretmeninin 3D stratejisiyle gerçekleştirilen öğrenme sürecinin öğrencinin anlama becerisinin gelişimine, (2) derse katılımına ve (3) özgüvenine etkisinin olup olmadığına yönelik düşüncelerini elde etmek için hazırlanmıştır. Katılımcıların sorulara öncelikle "evet, hayır veya kısmen" şeklinde bir yanıt vermeleri, ardından vermiş oldukları yanıtları açıklamaları istenmiştir. Tüm katılımcıların verdikleri yanıtlar araştırmacılar tarafından not edilerek kayıt altına alınmıştır.

\section{Uygulama Süreci}

Uygulama süreci, sırasıyla 3D stratejisi öğretimi için ön koşul becerileri geliştirme ve stratejileri tartışma, model olma, rehberli uygulamalar ve bağımsız uygulamalar aşamalarından oluşmaktadır. Uygulamaya yönelik aşamalar aşağıda detaylandırılmıştır.

3D stratejisi öğretimi. 3D stratejisi öğretimi haftada iki oturum olacak şekilde toplamda 12 oturumda gerçekleştirilmiştir. 3D stratejisinin öğretiminde kendini düzenleme strateji gelişimi yaklaşımının strateji öğretim basamakları kullanılmıştır. Bu amaçla stratejinin öğretimi; ön koşul becerileri geliştirme, stratejileri tartışma, model olma, rehberli uygulamalar ve bağımsız uygulamalar aşamalarından oluşmaktadır (Mason ve diğ., 2012a). Bu aşamalar doğrultusunda öğretimi yapılan 3D stratejisinin öğretim planları oluşturulmuştur. Ayrıca bu planların etkili bir şekilde uygulanmasında oturumlarda 3D kontrat (Bk. Ek A), 3D strateji öğretim kağıdı (Bk. Ek B), 3D kontrol listesi (Bk. Ek C) ve 3D roketleri (Bk. Ek D) kullanılmıştır. 3D kontratı, katılımcının okuma öncesinde 3D stratejisindeki bütün adımları kullanması için amaç oluşmasını sağlamaktadır. 3D strateji öğretim kağıdı ile katılımcının strateji adımlarını öğrenmesi sağlanırken aynı zamanda kendi kendine öğretimi teşvik etmeyi amaçlanmaktadır. Katılımcının 3D kontrol listesi kullanması, strateji adımlarını eksiksiz ve doğru yapmasını, böylelikle kendisini izlemesine olanak vermektedir. 3D roketleri ise katılımıının strateji adımlarını tamamladıktan sonra, stratejide ki kaç adımı doğru bir şekilde yaptığını ve okuma sonrasında kendini pekiştirmesini sağlamaktadır (Mason, 2002).

Strateji öğretiminde önkoşul becerileri geliştirme ve tartışma aşaması. Katılımcıya okuduğunu anlama stratejilerinin öğretileceği, bu stratejilerin okuduklarını hatırlamalarına yardımcı olacağı belirtilmiştir. Okuduklarını anladıklarında ve hatırladıklarında okuma ile ilgili soruları daha doğru ve daha ayrıntılı yanıtlayabileceklerinin altı çizilmiş ve bunun hem sözlü hem de yazılı cevaplarda işe yaracağı belirtilmiştir. Öncelikle kişiler, yerler, olaylar ve nesneler hakkında bir şeyler okurken iyi bir okuyucunun yapması gereken bazı şeyler olduğu kısaca tartışılmıştır. Bu oturumda yeni stratejiler öğrenecek olmalarına ek olarak bu stratejilerin okuma öncesinde mi, sırasında mı yoksa okumadan sonra mı kullanmalarının okuduklarını anlamalarına faydalı olacağını da öğrenecekleri belirtilmiştir. Katılıcılara okuma sürecinde tamamlamaları gereken adımlar olduğu söylenmiştir. Katılıcılara 3D görseli (Bkz. Ek E) gösterilerek, yolculuk örneği verilmiştir. Yolculuk örneğinde, sürücünün yolculuk öncesi, sırası ve sonrası yapması gerekenler okuma sürecindeki adımlarla ilişkilendirerek 3D’nin adımları açıklanmıştır.

Strateji öğretiminde model olma süreci. 3D stratejisinin okuma öncesi, okuma sırası, okuma sonrası basamaklarındaki strateji adımlarının metin üzerinde uygulamasına yönelik katılımcılara model olunmuştur. Model olma sürecinde sesli düşünme, beyin fırtınası ve etkileşimsel diyaloglar kullanıımıştır. 3D stratejisi adımlarını söylemesi rehberli uygulamaya geçiş için ölçüt olarak kabul edilmiştir.

Strateji öğretiminde rehberli uygulama süreci. Katılımcının 3D’nin okuma öncesi, okuma sırası ve okuma sonrası basamaklarındaki strateji adımlarının isimlerini sırayla yazması ve söylemesi rehberli uygulamalar aşamasına geçiş ölçütü olarak belirlenmiştir. Bu aşamada katılımcılardan 3D'nin okuma öncesi, okuma sırası ve okuma sonrası basamaklarındaki strateji adımlarını verilen metin üzerinde uygulamaları istenmiştir. Bu aşamada katılımcılara stratejileri uygulamada gereksinim 
duyuldukça rehberlik yapılmıştır. Gereksinimler dahilinde katılımcılara ipucu, dönüt ve düzeltmeler verilmiştir. Bu aşamada 3D Kontrol Listesinin katılımcılar tarafından kullanılması sağlanmıştır. Bu stratejileri adımlarının katılımcı tarafından ezbere söylenmesi ve uygulanması bağımsız uygulamaya geçiş için ölçüt olarak kabul edilmiştir.

Strateji öğretiminde bağımsız uygulama süreci. Katılımcılardan 3D stratejisinin okuma öncesi, okuma sırası ve okuma sonrası basamaklarındaki strateji adımlarını eksiksiz bir şekilde metin üzerinde bağımsız olarak uygulamaları bağımsız uygulamalar aşaması için ölçüt olarak belirlenmiştir. Katılımcıların bu stratejileri bağımsız olarak yapmaları sağlanmıştır. Bu bağlamda ihtiyaç duyulduğunda dönüt ve düzeltmeler kullanılmıştır. Katılımcı, 3D’nin dokuz adımını da metin üzerinde başarılı bir şekilde uygulama ölçütünü karşılayınca oturum sonlandırılmıştır.

\section{Verilerin Analizi}

Uygulama süreci tamamlandıktan sonra ortamdan elde edilen ses kayıtları yazıya çevrilmiş, daha sonra içerik analizi yapıımıştır. Krippendorff (2003) içerik analizinde kategorilerinin oluşturulması ve kodlama işlemlerinin yapılmasında, birden fazla değerlendirmeci kullanılmasının güvenirlik açısından önemli bir adım olduğunu belirtmiştir. Bu doğrultuda, okuduğunu anlama stratejileri hakkında bilgi sahibi olan iki değerlendirici tarafından katılımcıların kullandığı stratejiler değerlendirilmiştir. ỉki değerlendirmeci tarafından yapılan bağımsız kodlama sonucunda ulaşılan kod ve kategoriler karşılaştırılmıştır. Bu süreçte yapılan kodlamanın güvenirlik katsayısı 90 olarak hesaplanmıştır. Ayrıca okuduğunu anlamada uzman iki gözlemciye her katılımcı için 3D öğretim süreci olan model olma, rehberli uygulamalar ve bağımsız uygulamalar oturumlarına ait videolardan en az bir örnek seçilmiş ve her katılımcı için kayıtların en az \%33.33'ü izlettirilmiştir. Buna göre; model olma, rehberli uygulamalar ve bağımsız uygulamalar oturumlarının uygulama güvenirliği \%93.75 ile \%100 olarak bulunmuştur.

\section{BULGULAR}

\section{Sesli Düşünme Tekniği ile Elde Edilen Bulgular}

3D strateji öğretiminin katılımcıların okuduğunu anlamaya yönelik bilişsel ve üstbilişsel stratejileri kazanmalarına etkisi öğretim öncesi ve sonrasında sesli düşünme tekniği ve yarı yapılandırılmış görüşme kullanılarak değerlendirilmiştir. Aşağıda elde edilen bulgular ve yorumları sunulmuştur.

Öğretim öncesi. Öğretim öncesinde katılımcıların hangi bilişsel ve üstbilişsel stratejileri kullandıklarını belirlemek amacıyla sesli düşünme tekniği ile yapılan değerlendirmede her üç katılımcı da okuma öncesinde metni anlamak için herhangi bir strateji kullanmamıştır. Doğrudan okumaya başlayan katılımcılar metnin sonuna kadar durmadan okumuş, metni anlamak için çok az süre harcamış ve strateji kullandıklarına ilişkin herhangi bir ifade ve davranış sergilememişlerdir.

Öğretim sonrası. 3D stratejisi öğretiminin öğrencilerin bilişsel ve üstbilişsel stratejileri kazanmalarında etkili olup olmadığını belirlemek amacıyla kullanılan sesli düşünme tekniği sonucu öğretim sonrasında katılımcıların strateji kullanımının önemli ölçüde arttığı belirlenmiştir. Elde edilen bulgular Tablo 1'de verilmiştir.

Tablo 1. Öğretim sonrasında katılımcıların kullandıkları bilişsel ve üstbilişsel stratejiler

\begin{tabular}{|c|c|c|c|}
\hline & Kategori & Kod & Katılımcı \\
\hline \multirow{5}{*}{ Okuma Öncesi } & Tahmin etme & Başlığa bağlı metin tahmini & K1, K2 \\
\hline & \multirow{3}{*}{ Amaç oluşturma } & Başlığa bakma & K1, K2 \\
\hline & & ilk paragrafı okuma & $\mathrm{K} 1, \mathrm{~K} 2$ \\
\hline & & Ne öğrenmek istediği hakkında düşünme & K1, K3 \\
\hline & Geçmiş bilgileri aktifleştirme & Ne bildiği hakkında düşünme & $\mathrm{K} 1, \mathrm{~K} 2, \mathrm{~K} 3$ \\
\hline \multirow{4}{*}{ Okuma Sırası } & \multirow{4}{*}{ Anlamayı izleme } & Önemli yerlerin altını çizme & $\mathrm{K} 1, \mathrm{~K} 2, \mathrm{~K} 3$ \\
\hline & & Anlaşılmayan yerleri tekrar okuma & $\mathrm{K} 1, \mathrm{~K} 2, \mathrm{~K} 3$ \\
\hline & & Okuma hızını düşünme & $\mathrm{K} 1, \mathrm{~K} 2$ \\
\hline & & Önceki bilgilerle ilişkilendirme & K1 \\
\hline \multirow{3}{*}{ Okuma Sonrası } & Çıkarım yapma & Ana fikri bulma & $\mathrm{K} 1, \mathrm{~K} 2$ \\
\hline & \multirow[b]{2}{*}{ Anlamayı değerlendirme } & Ne öğrendiği hakkında düşünme & K1, K3 \\
\hline & & Özet bilgiler hakkında düşünme & $\mathrm{K} 1, \mathrm{~K} 3$ \\
\hline
\end{tabular}

K1: Birinci katılımcı, K2: İkinci katılımcı, K3: Üçüncü katılımcı

Tablo 1 incelendiğinde, öğretim sonrasında birinci katılımcının kullandığı bilişsel ve üstbilişsel stratejilerin tüm okuma aşamalarında önemli ölçüde arttığı ve çeşitlendiği ortaya çıkmıştır. Katılımcının okuma öncesinde "... metni ilk elime aldığımda başlığa bakarım ...", okuma sırasında “... bu cümleyi anlamadım tekrar okumam gerekiyor ..." gibi ifadeler kullandığı gözlenmiştir. İkinci katılımcının kullandığı bilişsel ve üstbilişsel stratejilerin okuma öncesi ve okuma sırası aşamalarında önemli ölçüde arttığı ve çeşitlendiği, okuma sonrasında ise bir strateji kullandığı gözlenmiştir. Katılımcının okuma sırasında “... burası önemli bir bilgi buranın altını çizmeliyim ...", “... hızlı okuyorum, hızımı biraz düşürmeliyim ...” gibi ifadeler kullandığı görülmüştür. Üçüncü katılımcının kullandığı bilişsel ve üstbilişsel stratejilerin tüm okuma aşamalarında önemli ölçüde arttığı ve çeşitlendiği tespit edilmiştir. Katılımcının okuma sonrasında “... metni okudum, sıra okuduklarımı özetlemeye geldi ...”, okuma sırasında “... burası önemli altını çizmeliyim ..." gibi ifadeler kullandığı gözlenmiştir. Sonuç olarak, 3D stratejisi öğretimi katılımcıların metni anlamak 
için kullandığı okuma öncesi, okuma sırası ve okuma sonrası strateji çeşitliliğini artırmıştır. Bu nedenle 3D strateji öğretiminin öğrenme güçlüğü olan öğrencilerin bilişsel ve üstbilişsel stratejileri kazanmalarında etkili olduğu ifade edilebilmektedir.

\section{Yarı Yapılandırılmış Görüşme ile Elde Edilen Bulgular}

Öğretim öncesi. Yarı yapılandırılmış görüşmeler sonucu katılımcıların öğretim öncesinde kullandıkları bilişsel ve üstbilişsel stratejiler Tablo 2' de özetlenmiştir.

Tablo 2. Öğretim öncesinde katılımcıların verdiği yanıtlara ilişkin bulgular

\begin{tabular}{|c|c|c|c|}
\hline & Kategori & Kod & Katılımcı \\
\hline \multirow{2}{*}{ Okuma Öncesi } & \multirow{2}{*}{ Tahmin etme } & Görsele bağlı metin tahmini & K1 \\
\hline & & Başlığa bağlı metin tahmini & K1 \\
\hline \multirow{3}{*}{ Okuma Sırası } & İki defa okuma & Sesli ve sessiz okuma & $\mathrm{K} 1, \mathrm{~K} 2$ \\
\hline & \multirow{2}{*}{ Anlamayı izleme } & Önemli yerlerin altını çizme & K1 \\
\hline & & Anlaşılmayan yerleri iki defa okuma & K3 \\
\hline \multirow{3}{*}{ Okuma Sonrası } & \multirow{2}{*}{ Tekrar okuma } & Bir kez daha okuma & $\mathrm{K} 1, \mathrm{~K} 2, \mathrm{~K} 3$ \\
\hline & & Başkası tarafından okunması & $\mathrm{K} 2$ \\
\hline & Anlamayı değerlendirme & Sorulara cevap verme & K3 \\
\hline
\end{tabular}

Tablo 2 incelendiğinde birinci katılımcının, bilişsel ve üstbilişsel stratejilere tüm okuma aşamalarında sınırlı düzeyde sahip olduğu belirlenmiştir. Örneğin, katılımcı yarı yapılandırımış görüşmede, okuma öncesinde “... metni daha iyi anlamak için resme bakarım ...", okuma sonrasında "... metni daha anlamak için metni tekrar okurum ..." gibi ifadeler kullanmıştır. İkinci katılımcının, bilişsel ve üstbilişsel stratejilere okuma sırası ve sonrası aşamalarında sınırlı düzeyde sahip olduğu, okuma öncesinde ise herhangi bir strateji kullanmadığı ortaya çıkmıştır. Katılımcı yarı yapılandırılmış görüşmede, okuma sonrasında “... metni daha anlamak için iki defa okurum ...", "... başkasının bana okumasını isterim ...” gibi ifadeler kullanmıştır. Üçüncü katılımcının ise bilişsel ve üstbilişsel stratejilere okuma sırası ve sonrası aşamalarında sınırlı düzeyde sahip olduğu okuma öncesinde herhangi bir strateji kullanmadığı belirlenmiştir. Katılımcı yarı yapılandırılmış görüşmede, okuma sonrasında "... anlamadığım yerleri anlamak için tekrar okurum ...", “... sorulan soruları cevaplarım ..." gibi ifadeler kullanmıştır.

Sonuç olarak, birinci katılımcının metni anlamak için okuma öncesi, okuma sırası ve okuma sonrası strateji bilgisinin sınırlı olduğu belirlenmiştir. İkinci ve üçüncü katılımcıların da okuma öncesinde metni anlamak için herhangi bir stratejiye sahip olmadığı, okuma sırası ve sonrasında ise sahip oldukları stratejilerin ise oldukça sınırlı sayıda olduğu gözlenmiştir.

Öğretim sonrası. 3D stratejisi öğretimi sonucu yarı yapılandırılmış görüşmeler ile katılımcıların sahip olduğu belirlenen bilişsel ve üstbilişsel stratejiler Tablo 3'de özetlenmiştir.

Tablo 3. Öğretim sonrasında katılımcıların verdiği yanıtlara ilişkin bulgular

\begin{tabular}{|c|c|c|c|}
\hline & Kategori & Kod & Katılımcı \\
\hline \multirow{8}{*}{ Okuma Öncesi } & \multirow{3}{*}{ Tahmin etme } & Görsele bağlı metin tahmini & K1 \\
\hline & & Başlığa bağlı metin tahmini & $\mathrm{K} 1, \mathrm{~K} 2$ \\
\hline & & Metne göz gezdirmek & $\mathrm{K} 2$ \\
\hline & \multirow{4}{*}{ Amaç oluşturma } & Başlığa bakma & $\mathrm{K} 1, \mathrm{~K} 2$ \\
\hline & & İlk paragrafı okuma & $\mathrm{K} 1, \mathrm{~K} 2$ \\
\hline & & Yazarın amacı hakkında düşünme & K1 \\
\hline & & Ne öğrenmek istediğim hakkında düşünme & $\mathrm{K} 1, \mathrm{~K} 3$ \\
\hline & Geçmiş bilgileri aktifleştirme & Ne bildiğim hakkında düşünme & $\mathrm{K} 1, \mathrm{~K} 2, \mathrm{~K} 3$ \\
\hline \multirow{5}{*}{ Okuma Sırası } & \multirow{3}{*}{ Anlamayı izleme } & Önemli yerlerin altını çizme & $\mathrm{K} 1, \mathrm{~K} 2$ \\
\hline & & Anlaşılmayan yerleri tekrar okuma & $\mathrm{K} 1, \mathrm{~K} 2, \mathrm{~K} 3$ \\
\hline & & Okuma hızını düşünme & $\mathrm{K} 1, \mathrm{~K} 2, \mathrm{~K} 3$ \\
\hline & \multirow[t]{2}{*}{ Anlamlandırma } & Zihinde canlandırma & K1, K3 \\
\hline & & Önceki bilgilerle ilişkilendirme & $\mathrm{K} 1, \mathrm{~K} 2$ \\
\hline \multirow{6}{*}{ Okuma Sonrası } & \multirow{2}{*}{ Tekrar okumak } & Bir kez daha okuma & $\mathrm{K} 1, \mathrm{~K} 2$ \\
\hline & & Önemli bölümleri tekrar okuma & K1 \\
\hline & \multirow{2}{*}{ Çıkarım yapmak } & Ana fikri bulma & $\mathrm{K} 1, \mathrm{~K} 2$ \\
\hline & & Farklı bir başlık bulma & K1 \\
\hline & \multirow{2}{*}{ Anlamayı değerlendirme } & Ne öğrendiği hakkında düşünme & $\mathrm{K} 1, \mathrm{~K} 2, \mathrm{~K} 3$ \\
\hline & & Özet bilgiler hakkında düşünme & $\mathrm{K} 3$ \\
\hline
\end{tabular}

Tablo 3 incelendiğinde, tüm katılımcıların sahip olduğu bilişsel ve üstbilişsel stratejilerin tüm okuma aşamalarında önemli ölçüde arttığı ve çeşitlendiği belirlenmiştir. Birinci katılımcı yarı yapılandırılmış görüşmede, okuma öncesinde "... metni daha anlamak için okuyacağım metin hakkında ne bildiğimi düşünürüm ...", okuma sonrasında “... okuduktan sonra metinden ne öğrendiğimi düşünürüm ..." gibi ifadeler kullanırken, ikinci katılımcı "... metni daha anlamak için önce ilk paragrafı okurum ...", okuma sırasında "... anlaşılmayan yerleri bir kez daha okurum ..." gibi ifadeler kullanmıştır. Üçüncü katılımcı da benzer şekilde, 
okuma öncesinde “... metni daha iyi anlamak için okumadan önce ne öğrenmek istediğim hakkında düşünürüm ...", okuma sırasında "... anlamadığım yerleri tekrar okurum ..." gibi ifadeler ile kullandığı stratejiler hakkında bilgi vermiştir. Sonuç olarak 3D stratejisi öğretimi öğretim öncesine göre her üç katılımcının da strateji çeşitliliğini artırmıştır. Bu nedenle 3D strateji öğretiminin öğrenme güçlüğü olan öğrencilerin bilişsel ve üstbilişsel stratejileri kazanmalarında etkili olduğu ifade edilebilmektedir.

\section{Çalışmanın Sosyal Geçerliliğine iliş̧kin Görüşler}

Katılımcı öğrenciler, formda yer alan dört sorunun hepsine "evet" cevabını vererek, 3D stratejisi hakkında olumlu görüş sunmuşlardır. 3D stratejisini öğrenmelerinin okuma sürecine daha aktif katılmalarını ve böylelikle anlamalarının geliştiğini ifade etmişlerdir. Ayrıca 3D stratejisi öğrenme ve uygulama sürecinin zevkli olduğunu belirtmişlerdir. Katılımcılara 3D stratejisini uygulamanın kolay olup olmadığı ile ilgili soru sorulduğunda, öğretimin başında kısmen zorlansalar da ileriki süreçlerde kolaylıkla uygulayabildiklerini söylemişlerdir. Katılımcılara 3D stratejisini bundan sonra da okurken uygulamak isteyip istemedikleri ile ilgili soru sorulduğunda, bu stratejiyi kullanmalarının anlamalarını geliştirdiği, başarılarını artırdığını dolayısıyla ileriki okumalarında kullanacaklarını belirtmişlerdir. Sıra arkadaşları, çalışma sonunda arkadaşlarının anlama becerilerinde gördükleri değişiklikleri anlatmalarına yönelik soruya, arkadaşının okuduğu metni daha iyi anladığını belirtmişlerdir. Ayrıca derslere katılmada daha istekli olduğunu, sorulara cevap verme, tahtaya çıkma gibi davranışlarının arttığını böylelikle kendine olan özgüvenlerinin arttığını belirtmişlerdir.

Öğretmenler, üç sorunun hepsine "evet" cevabını vererek, olumlu görüş sunmuşlardır. Öğretmenler öğrencilerin almış oldukları 3D stratejisi eğiminin öğrencilerin anlama becerilerini geliştirdiğini, metni anlama için çaba gösterdiklerini ve derse katılımlarının arttığını söylemişleridir. Öğrencilerin başarılarının artmasıyla beraber özgüvenlerinde de bir artış olduğunu belirtmişlerdir. Ayrıca bu stratejinin metni anlamada etkili olduğunu ve kendilerine bu strateji öğretimini ile ilgili bilgi verildiği taktirde derslerde kullanabileceklerini ifade etmişlerdir. Bütün bu bulgular ışığında, 3D stratejisinin kullanımının kolay olup farklı derslerde kullanılabileceği ve katılımcıların okuma sürecine aktif bir biçimde katılımlarını sağladığı görülmektedir. Sonuç olarak bu uygulamanın sosyal geçerliliğinin yüksek olduğu söylenebilir.

\section{TARTIŞMA}

Bu araştırmada, 3D strateji öğretiminin öğrenme güçlüğü olan öğrencilerin bilişsel ve üstbilişsel stratejileri kazanmalarına olan etkisi araştırılmıştır. Elde edilen sonuçlar, 3D strateji öğretiminin öğrenme güçlüğü olan öğrencilerin bilişsel ve üstbilişsel stratejileri kazanmalarına katkı sağladığını göstermiştir. Alanyazında da öğrenme güçlüğü olan öğrencilerin bilişsel ve üstbilişsel stratejileri öğrenebildiklerini gösteren çok sayıda çalışmaya rastlamak mümkündür (Berkeley \& Riccomini, 2011; Botsas \& Padeliadu, 2003; Dehghani, Amiri, \& Moulavi, 2008; Dewitz \& Dewitz, 2003; Esser, 2001; Franco-Castillo, 2013). Ayrıca mevcut araştırmada olduğu gibi 3D strateji öğretiminin öğrencilerin bilişsel ve üstbilişsel stratejileri kazanmalarında etkili olduğunu gösteren çok sayıda çalışma bulunmaktadır (Johnson ve diğ., 2011; Mason ve diğ., 2012b; Roohani \& Asiabani, 2015). Örneğin, Mason ve diğerleri (2013), tarafından ifade edildiği gibi 3D strateji öğretimi hedef oluşturma, kendini izleme, kendini yönetme ve kendini pekiştirme stratejilerinin kazanımı konusunda oldukça etkili bir stratejidir. Bu açıdan, araştırmadan elde edilen bulgular önceki çalışmaların sonuçları ile uyumludur. Nitekim 3D stratejisi öğretiminde, her oturum öncesi strateji adımlarının öğrenilmesine yönelik amaç oluşturmak için kontrat, kendini izlemek amacıyla 3D kontrol listesi, kendini yönetmeyi sağlamak amacıyla 3D strateji öğretim kağıdı ve kendini pekiştirmek amacıyla 3D roketleri kullanılmıştır. Tüm bunlar öğrencilerin okumaya yönelik amaç oluşturmalarını, anlamalarını izlemelerini ve değerlendirmelerini sağlayacak stratejileri kazanmalarında ve etkili bir şekilde kullanmalarında önemli rol oynamıştır.

Öğretim öncesinde sesli düşünme tekniğiyle yapılan okumada katılımcıların doğrudan okumaya başladığı, sesli düşünmeleri konusunda uyarılmalarına rağmen metnin sonuna kadar sadece okumaya odaklandıkları ve metni anlamak için herhangi bir strateji kullanmadıkları gözlenmiştir. Öğretim sonrasında sesli düşünme tekniğiyle yapılan okumada ise bu katılımcıların okuma öncesinde tahmin etme, amaç oluşturma, geçmiş bilgileri etkinleştirme; okuma sırasında anlamayı izleme ve tekrar; okuma sonrasında ise çıkarım yapma ve anlamayı değerlendirme gibi stratejiler kullandıkları gözlenmiştir. Yarı yapılandırılmış görüşmelerde, öğretim öncesinde katılımcıların okuma öncesinde, sırasında ve sonrasında kullanılabilecek sınırlı sayıda strateji bilgisine sahip oldukları anlaşılmıştır. Öğretim sonrasında ise okuma öncesinde tahmin etme, amaç oluşturma, geçmiş bilgileri etkinleştirme; okuma sırasında anlamalarını izleme, anlamlandırma; okuma sonrasında tekrar okumak, çıkarım yapmak ve anlamayı değerlendirme stratejilerini kullandıkları ortaya çıkmıştır. Bu sonuç, 3D stratejisi öğretimiyle öğrencilere okuma öncesi, sırası ve sonrasında kullanabilecekleri stratejilerin kazandırılı̆̆ını göstermektedir. Bununla birlikte, yapılan araştırmalarda 3D strateji kullanan öğrencilerin okuduklarını anlamada daha başarılı oldukları belirlenmiştir (Hedin ve diğ., 2011; Howorth ve diğ., 2016; Hoyt, 2010; Mason, 2004; Mason ve diğ., 2006; Meadan \& Mason, 2007). Bu açıdan, mevcut çalışmada da katılımcıların bu stratejileri kazanmış olmalarının okuduklarını anlamalarına katkı sağlayacağı düşünülmektedir.

Katılımcıların öğretim öncesi kullandıkları stratejiler incelendiğinde ikinci ve üçüncü katılımcının okuma öncesi stratejileri hiç kullanmadı̆̆ı, birinci katılımcının ise sınırlı sayıda strateji kullandı̆̆ı belirlenmiştir. Okuma sırasında kullandıkları stratejiler incelendiğinde anlamalarını izlemelerini ve kontrol etmelerini sağlayacak strateji kullanımlarında üç katılımcının da oldukça yetersiz olduğu belirlenmiştir. Okuma sonrasında ise katılımcıların anlamalarını değerlendirmeleri için gerekli olan stratejileri kullanamadıkları gözlenmiştir. Buna karşın, öğretim sonrasında üç katılımcının da genel anlamda 3D stratejisinde yer alan adımlara yönelik stratejileri kazandıkları ve kullandıkları belirlenmiştir. Buna karşın elde bulgulardan katılımcıların 3D stratejisinde yer alan 
okuma öncesinde yazarın amacı hakkında düşünme stratejisini kullanmadıkları, yine yapılan yarı yapılandırılmış görüşmede ikinci ve üçüncü katılımcıların bu adımdan bahsetmediği görülmüştür. Diğer taraftan, katılımcılar bu strateji adımından bahsetmeseler de başlığa bakma ve ilk paragrafı okuma gibi davranışları sergilemelerinin yazarın amacı hakkında düşünmelerine yönelik olabileceği akla gelmektedir.

Birinci katılımcı, öğretim sonunda bilişsel ve üstbilişsel stratejileri kullanmada diğer iki katılımcıya göre önemli bir gelişme göstermiştir. Uygulama öncesinde yapılan değerlendirmede bu katılımcının okuma öncesi, okuma sırası ve okuma sonrası belirli okuma stratejilerine sahip olduğu belirlenmiştir. Katılımcının sınırlı da olsa bu stratejilere sahip olmasının uygulama sürecinde öğrendiği üstbilişsel stratejileri daha etkili kullanmasına katkı sağladığı düşünülmektedir. Katılımcının stratejileri etkili kullanması, okuduğunu anlama becerisinin gelişmesine ve sonuç olarak daha sonraki zamanlarda da bu davranışları tekrar etmesini sağlamıştır. Böylelikle, katılımcının okuma sürecine daha fazla strateji kullanmaya motive olduğu düşünülmektedir. Nitekim yapılan araştırmalarda, motivasyon ile okuma stratejilerinin kullanımı arasında karşılıklı bir ilişki olduğunu (Lau \& Chan, 2003; Van Kraayenoord \& Schneider, 1999) ve okuduğunu anlama sürecinde motivasyonunda önemli bir unsur olduğu vurgulanmaktadır (Logan ve diğ., 2011; Mastropieri \& Scruggs, 2007; Stetter \& Hughes, 2011).

Katılımcıların öğretim öncesinde sesli düşünme tekniği ile oldukça sınırlı sayıda strateji kullanmalarında geçmiş yaşantılarının ve sosyo-kültürel özelliklerinin etkili olduğu da söylenebilir. Nitekim katılımcıların düşük sosyo-ekonomik düzeye sahip çevrelerdeki okullarda öğrenim gördükleri bilinmektedir. Başka bir deyişle, düşük sosyo-ekonomik düzeydeki çevrelerde yaşayan öğrencilerin düşündüklerini ifade etmede yeterli olmadıkları söylenebilir. Diğer taraftan okuma güçlüğü olan öğrencilerin sesli düşünme becerilerinin zayıf olduğu da bilinmektedir (Walker, 2005). Ayrıca, uygulama süreci araştırmacılar tarafından yapıldığı için öğrenciler sürecin başında araştırmacıları daha iyi tanımadıklarından çekingen davranmışlardır. İlgili literatürde de öğrenme güçlüğü olan öğrencilerin içe kapanık davranışlar sergiledikleri, genellikle sessiz oldukları, dikkat çekince utandıkları ve akademik başarısızlıklarının başkaları tarafından görülebileceği endişesi taşıdıkları belirtilmektedir (Bender \& Golden, 1990; Sze, 2010). Bütün bunlar öğretim öncesinde bu sonucun ortaya çıkmasını etkilemiş olabilir. Araştırmacılar 3D stratejisi öğretim sürecinde sesli düşünmüş, etkileşimli diyaloglara yer vermiştir. Öğrencileri de bu süreçlerde sesli düşünmeye teşvik etmiştir. Bu uygulamaların, öğretim sonrasında yapılan sesli düşünme tekniğinin daha başarılı sonuçlara ulaşılmasında etkili olduğu söylenebilir.

Bu araştırmada ulaşılan diğer bir sonuç ise 3D stratejisinin sosyal geçerliliğinin de yüksek olduğudur. Araştırmaya katılan öğrencilere, sıra arkadaşlarına ve öğretmenlerine sorulan sorulara verilen yanıtlardan 3D strateji öğretiminin öğrencilerin anlama becerilerinin gelişimini, bu beceriyi farklı derslerde kullanmalarını, okula ve derslere yönelik olumlu tutum geliştirmelerini ve derse katıım düzeylerinin artmasını sağladığı anlaşılmıştır. Bu sonuç, öğrencilerin kazandıkları anlama becerilerini farklı ortamlarda ve disiplinlerde kullandıklarını göstermektedir. Ulaşılan bu sonuç, 3D stratejisi öğretiminin sosyal geçerliliğinin yüksek olduğu diğer çalışmalarla da desteklenmektedir (Hedin ve diğ., 2011; Hoyt, 2010; Howort, 2015; Mason ve diğ., 2006a; Mason ve diğ., 2013; Meadan ve Mason, 2007). Tüm sonuçlar birlikte ele alındığında, özetle 3D strateji öğretiminin araştırmaya katılan öğrencilerin okuma öncesi, okuma sırası ve okuma sonrası birçok bilişsel ve üstbilişsel stratejileri kazanmalarında etkili olduğunu söylemek mümkündür.

$\mathrm{Bu}$ araştırmanın sonuçlarını değerlendirirken göz önünde bulundurulması gereken bazı sınırlılıkları da vardır. illk olarak, 3D strateji öğretimi üç katılımcı ile yapıımıştır. Bu durum bulguların genellenmesini sınırlandırmaktadır. Bu amaçla 3D’nin etkililiğinin büyük gruplarda veya başka öğrenme özellikleri olan gruplarda deneysel olarak incelenmesinin önemli olacağı düşünülmektedir. Ek olarak, 3D strateji öğretiminin etkisinin başka stratejiler veya strateji paketleri öğretiminin etkileri ile karşılaştırmaları olarak incelenmesinin stratejinin etkililiğine ilişkin daha geçerli sonuçlar elde edilmesine katkı sağlayacağı düşünülmektedir. Mevcut çalışmada 3D strateji öğretiminin araştırmaya katılan öğrencilerin bilişsel ve üstbilişsel stratejileri kazanmalarındaki etkililiği incelenmiştir. Oysa bu stratejilerin diğer metin türlerine genellenmesi ve strateji kullanımının kalıcılığı da önemlidir. Bu nedenle ilerde yapılacak çalışmalarda 3D strateji öğretimi ile kazanılan bilişsel ve üstbilişsel stratejilerin öğrenme güçlüğü olan öğrencilerde ne düzeyde genellenebildiğinin ve ne kadar süre ile koruyabildiğinin incelenmesi de önerilmektedir.

\section{KAYNAKÇA}

Afflerbach, P. (2000). Verbal reports and protocol analysis. In M. L. Kamil, P. B. Mosenthal, P.D. Pearson \& R. Barr (Eds.), Handbook of reading research (pp. 163-179). Mahwah, NJ: Erlbaum.

Alqahtani, S. S. S. (2016). The effect of using a tablet and a meta-cognitive strategy to improve reading comprehension skills for students with SLD (Doctoral Dissertation). Available from ProQuest Dissertations and Theses database. (UMI No.10143071)

Al-Shaye, S. S. (2002). The effectiveness of metacognitive strategies on reading comprehension and comprehension strategies of eleventh grade students in Kuwaiti high schools (Doctoral Dissertation). Available from ProQuest Dissertations and Theses database. (UMI No.3062144)

Anastasiou, D., \& Griva, E. (2009). Awareness of reading strategy use and reading comprehension among poor and good readers. Elementary Education Online, 8(2), 283-297.

Arabacı, G. (2017). Öğrenme güçlüğü olan ve olmayan çocuklarda akıcı okuma ve okuduğunu anlama becerileri arasındaki ilişkinin incelenmesi. Yayınlanmamış Yüksek Lisans Tezi, Ankara Üniversitesi, Ankara.

Baker, L., \& Brown, A. L. (1984). Metacognitive skills and reading. In P. D. Pearson, R. Barr, M. L. Kamil, ve P. Mosenthal (Eds.), Handbook of reading research (pp. 353-394). New York: Longman.

Baydık, B. (2011). Okuma güçlüğü olan öğrencilerin üstbilişsel okuma stratejilerini kullanımı ve öğretmenlerinin okuduğunu anlama öğretim uygulamalarının incelenmesi. Eğitim ve Bilim, 36(162), 302-319.

| Kastamonu Eğitim Dergisi, 2020, Vol. 28, No. 3| 
Bender, W. N. (2002). Differentiating instruction for students with learning disabilities. Thousand Oaks, Ca: Corwin Press.

Bender, W. N., \& Golden, L. B. (1990). Subtypes of students with learning disabilities as derived from cognitive, academic, behavioral, and selfconcept measures. Learning Disability Quarterly, 13(3), 183-194.

Berkeley, S., Mastropieri, M. A., \& Scruggs T.E., (2011). Reading comprehension strategy instruction and attribution retrainin for secondary students with learning and other mild disabilities. Journal of Learning Disabilities, 44(1), 18-32.

Berkeley, S., \& Riccomini, P. R., (2011). QRAC-the-Code: A comprehension monitoring strategy for middle school social studies textbooks. Journal of Learning Disabilities, 46(2), 154-165.

Botsas, G. (2017). Differences in strategy use in the reading comprehension of narrative and science texts among students with and without learning disabilities. Learning Disabilities-A Contemporary Journal, 15(1), 121-144.

Botsas, G., \& Padeliadu, S. (2003). Goal orientation and reading comprehension strategy use among students with and without reading difficulties. International Journal of Educational Research, 39(4-5), 477-495.

Bosson, M. S., Hessels, M. G. P., Hessels-Schlatter, C., Berger, J. L., Kipfer, N. M., \& Büchel, F. P. (2010). Strategy acquisition by children with general learning difficulties through metacognitive training. Australian Journal Of Learning Difficulties, 15(1), 13-34.

Carrell, P. L. (1998). Can reading strategies be successfully taught? Australian Review of Applied Linguistics, 21, 1-20.

Coppins, L. S. (2008). Metacognition theory as related to reading strategies and reading comprehension at the fifth grade level (Doctoral Dissertation). Available from ProQuest Dissertations and Theses database. (UMI No. 3518996)

Crabtree, T., Alber-Morgon, R., \& Konrad, M. (2010). The effects of self-monitoring of story elements on the reading comprehension of high school seniors with learning disabilities. Education and Treatment of Children, 33(2), 187-203.

Cummins, C., Stewart, M. T., \& Block, C. C. (2005). Teaching several metacognitive strategies together increases students' independent metacognition. In S. Isreal, C. Block, K. Bauserman, \& K. Kinnucan- Welsch (Eds.), Metacognition in literacy learning: Theory, assessment, instruction, and Professional development (pp. 227-296). Mahwah: Lawrence Erlbaum Associates.

Dabarera, C., Renandya, W. A., \& Zhang, L.J. (2014). The impact of metacognitive scaffolding and monitoring on reading comprehension. System, 42, 462-473.

Dehghani, M., Amiri, S., \& Moulavi, H. (2008). Impact of attributional and metacognitive-attributional strategies training on reading comprehension in fourth grade female elementary students with dyslexia. Research on Exceptional Children, 4(26). 407-424.

Delimehmet-Dada, Ş., \& Ergül, C. (2020). Öğrenme güçlüğü olan ve olmayan öğrencilerin sözcük bilgisi ve okuduğunu anlama becerileri arasındaki ilişki. Ankara Üniversitesi Eğitim Bilimleri Fakültesi Özel Eğitim Dergisi, 21(1), 1-22.

Dermitzaki, I., Andreou, G., \& Paraskeva, V. (2008). High and low reading comprehension achievers' strategic behaviors and their relation to performance in a reading comprehension situation. Reading Psychology, 29(6), 471-492.

Dewitz, P., \& Dewitz, P. K. (2003). They can read the words, but they can't understand: Refining comprehension assessment. The Reading Teacher, $56,422-435$.

Doğanay-Bilgi, A. (2009). Zihinsel yetersizliği olan öğrencilerin bilgi veren metinleri anlamalarında uyarlanmış çok öğeli bilişsel strateji öğretinin etkiliği. Yayınlanmamış Doktora Tezi, Gazi Üniversitesi, Eğitim Bilimleri Enstitüsü, Ankara.

Duke, N. K., Pearson, P. D., Strachan, S. L., \& Billman, A. K. (2011). Effective practices for developing reading comprehension. In A. E. Farstrup \& S. J. Samuels (Eds.). What research has to say about reading instruction (pp. 51-93). Newark, DE: International Reading Association.

Edmonds, M. S., Vaughn, S., Wexler, J., Reutebuch, C., Cable, A., Tackett, K. K., ...Schnakenberg, J. W. (2009). A synthesis of reading interventions and effects on reading comprehension outcomes for older struggling readers. Review of Educational Research, 79(1), 262-300.

Esser, M. S. (2001). The effects of metacognitive ve strategy training and attribution retraining on reading comprehension in African-American students with learning disabilities (Doctoral Dissertation). Available from ProQuest Dissertations and Theses database. (UMI No. 3021672)

Flavell, J. H. (1979). Metacognition and cognitive monitoring: A new area of cognitive developmental inquiry. American Psychologist, 34(10), 906-911.

Forness, S. R., Kavale, K. A., Blum, I. M., \& Lloyd, J. W. (1997). Mega-analysis of meta-analyses. Teaching Exceptional Children, $29(6), 4$.

Franco-Castillo, I. (2013). The relationship between scaffolding metacognitive strategies identified through dialogue journals and second graders' reading comprehension, science achievement, and metacognition using expository text (Doctoral Dissertation). Available from ProQuest Dissertations and Theses database. (UMI No. 3608709)

Gaddy, S. A. (2004). Teaching text-structure strategies to postsecondary students with learning disabilities to compare their reading comprehension performance on expository text (Doctoral Dissertation). Available from ProQuest Dissertations and Theses database. (UMI No. 3196666)

Gajria, M., Jitendra, A. K., Sood, S., \& Sacks, G. (2007). Improving comprehension of expository text in students with LD: A research synthesis. Journal of Learning Disabilities, 40, 210-225.

Galloway, A. M. (2003). Improving reading comprehension through metacognitive strategy instruction: Evaluating the evidence for the effectiveness of the reciprocal teaching procedure (Doctoral Dissertation). Available from ProQuest Dissertations and Theses database. (UMI No. 3092542)

Gersten, R., Fuchs, L., Williams, J. P., \& Baker, S. (2001). Teaching reading comprehension strategies to students with learning disabilities. Review of Educational Research, 71(2), 279-320.

Görgün, B., \& Melekoğlu, M. A. (2019). Özel öğrenme güçlüğü olan öğrencilerin akıcı okuma ve okuduğunu anlama becerilerini geliştirmeye yönelik okuma destek programının geliştirilmesi. ilköğretim Online, 18(2). 698-713 
Guthrie, J. T., \& Wigfield, A. (2000). Engagement and motivation in reading. In M. L. Kamil, P. B. Mobenthal, P. D. Pearson \& R. Barr (Eds.). Handbook of Reading Research (pp. 403-420). New York: Longman.

Hagaman, J. L., Luschen, K., \& Reid, R. (2010). The "RAP" on reading comprehension. Teaching Exceptional Children, 43(1), 22-29.

Harvey, S., \& Goudvis, A. (2013). Comprehension at the core. The Reading Teacher, 66(6), 432-439.

Hedin, L., Mason, L. H., \& Gaffney, J. (2011). Comprehension strategy instruction for two students with attention-related disabilities. Preventing School Failure, 55, 148-157.

Howorth, S., Lopata, C., Thomeer, M., \& Rodgers, J. (2016). Effects of the TWA strategy on expository reading comprehension of students with autism. British Journal of Special Education, 43(1), 39-59.

Hoyt, L. R. (2010). The effects of self regulated strategy development (srsd) on reading comprehension for secondary students with emotional and behavioral disabilities (Doctoral Dissertation). Available from ProQuest Dissertations and Theses database. (UMI No. 3424273)

Hughes, M. T., \& Parker-Katz, M. (2013). Integrating comprehension strategies into social studies instruction. The Social Studies, 104(3), 93-104.

Houtveen, A., \& Van de Grift, W. (2007). Effects of metacognitive instruction and instruction time on reading comprehension. School Effectiveness and School Improvement, 18(2), 173-190.

Johnson, J. W., Reid, R., \& Mason, L. H. (2011). Improving the reading recall of high school students with ADHD. Remedial and Special Education, 33(4), 258-268.

Karbalaei, A. (2011). Metacognition and reading comprehension. íkala, Revista de Lenguaje y Cultura, 16(28), 5-14.

Kendeou, P., Van Den Broek, P., Helder, A., \& Karlsson, J. (2014). A cognitive view of reading comprehension: Implications for reading difficulties. Learning Disabilities Research and Practice, 29(1), 10-16.

Kennedy, M. J., \& Deshler, D. D. (2010). Literacy instruction, technology, and students with learning disabilities: Research we have, research we need. Journal of Learning Disabilities, 33(4), 289-298.

Kim, W., Linan-Thompson, S., \& Misquitta, R. (2012). Critical factors in reading comprehension instruction for students with learning disabilities: A research synthesis. Learning Disabilities Research and Practice, 27(2), 66-78.

Krippendorf, K. (2003). Content analysis: An introduction to its methodology. California: SAGE Publications.

Kuhn, D., \& Dean, D. (2004). Metacognition: A bridge between cognitive psychology and educational practice. Theory into Practice, 43(4), 268273.

Lau, K. L., \& Chan, D. W. (2003). Reading strategy use and motivation among Chinese good and poor readers in Hong Kong. Journal of Research in Reading, 26(2), 177-190.

Lerner, J. (2000). Learning disabilities: Theories, diagnosis, and teaching strategies. Boston, USA: Houghton Mifflin.

Logan, S., Medford, E., \& Hughes, N. (2011). The importance of intrinsic motivation for high and low ability readers' reading comprehension performance. Learning and Individual Differences, 21(1), 124-128.

Mason, L. H. (2002). Self-Regulated strategy instruction: Effects on expository reading comprehension among students who struggle with reading (Doctoral Dissertation). Available from ProQuest Dissertations and Theses database. (UMI No. 3078326)

Mason, L. H. (2004). Explicit self-regulated strategy developmentversus reciprocal questioning: Effect on informational reading comprehension among struggling readers. Journal of Educational Psychology, 96, 283-296.

Mason, L. H., Dunn-Davison, M. D, Hammer, C. S., Miller, C. A., \& Glutting, J. (2012a). Knowledge, writing, and language outcomes for a reading comprehension and writing intervention. Reading and Writing: An Interdisciplinary Journal, 26, 1135-1158.

Mason L. H., Meadan-Kaplansky, H., Hedin, L. \& Taft, R. (2013). Self-Regulating informational text reading comprehension: Perceptions of lowachieving students. Exceptionality, 21,69-86.

Mason, L. H., Meadan, H., Hedin, L., \& Corso, L. (2006). Self-regulated strategy development instruction for expository text comprehension. Teaching Exceptional Children, 38, 47-52.

Mason, L. H., Meadan, H., Hedin, L. R., \& Cramer, A. M. (2012b). Avoiding the struggle: Instruction that supports students' motivation in reading and writing about content material. Reading and Writing Quarterly, 28(1), 70-96.

Mastropieri, M. A., \& Scruggs, T. E. (2007). The inclusive classroom: Strategies for effective instruction (4 ed.). New Jersey: Pearson.

Mastropieri, M. A., Scruggs, T. E., \& Graetz, J. E. (2003). Reading comprehension instruction for secondary students: Challenges for struggling students and their teachers. Learning Disability Quarterly, 26, 103-116.

Meadan, H., \& Mason, L. H. (2007). Reading instruction for a student with emotional disturbance: Facilitating understanding of expository text. Beyond Behavior, 16(2), 18-26.

Meneghetti, C., Carretti, B., \& De Beni, R. (2006). Components of reading comprehension and scholastic achievement. Learning and Individual Differences, 16, 291-301.

Mercer, C. D., \& Mercer, A. R. (2005). Teaching students with learning problems (7th ed.). Upper Saddle River, NJ: Merrill/PrenticeHall.

Merson, J. (2016). The Effect of the TWA reading strategy on the reading comprehension level of 9th - and 10th - grade students, (Master's Thesis, Goucher College). Ocak 2017'de https://mdsoar.org/bitstream/handle/11603/2817/MersonJennifer paper.pdf?sequence=1 adresinden ulaşılmıştır.

Moya, K. E. (1993). Learning strategy instruction: Exploring the potential of metacognition. Reading Improvement, 30(3), 130-133.

Padeliadu, S., \& Antoniou, F. (2014). The relationship between reading comprehension, decoding, and fluency in Greek: A cross-sectional study. Reading and Writing Quarterly, 30(1), 1-31. 
Palincsar, A. S., \& Brown, A. L. (1984). Reciprocal teaching of comprehensionfostering and comprehension-monitoring activities. Cognition and Instruction, 1(2), 117-175.

Pardo, (2004). What every teacher needs to know abaut comprehension. The Reading Teacher, 58(3). 272-280.

Paris, S. G., \& Myers, M. (1981). Comprehension monitoring, memory and study strategies of good and poor readers. Journal of Reading Behavior, $13,5-22$.

Pintrich, P. R. (2002). The role of metacognitive knowledge in learning, teaching, and assessing. Theory into Practice, 41(4), $219-225$.

Pressley, M., \& Afflerbach, P. (1995). Verbal protocols of reading: The nature of constructively responsive reading. Hillsdale, NJ: Erlbaum.

Pressley, M., \& Gaskins, I. (2006). Metacognitively competent reading comprehension is constructively responsive reading: How can such reading be developed in students? Metacognition Learning, 1(1), 99-113.

Rock, M. E. (2016) A case study on the impact of reading strategies on the comprehension of informational text for adolescent readers (Doctoral Dissertation). Available from ProQuest Dissertations and Theses database. (UMI No. 10120446)

Rogevich, M. E., \& Perin, D. (2008). Effects on science summarization of a reading comprehension intervention for adolescents with behavior and attention disorders. Exceptional Children, 74, 135-154.

Roohani, A., \& Asiabani, S. (2015). Effects of self-regulated strategy development on EFL learners' reading comprehension and metacognition. GEMA: Online Journal of Language Studies, 15(3), 31-49.

Root-Littlefield, A. (2011). The relations among summarizing instruction, support for student choice, reading engagement and expository text comprehension (Doctoral Dissertation). Available from ProQuest Dissertations and Theses database. (UMI No. 3481907)

Sanır, H. (2017). Öğrenme güçlügü olan ve olmayan ortaokul öğrencilerinde okuduğunu anlamayı etkileyen faktörlerin karşılaştırılması: Aracı model testi. Yayınlanmamış Doktora Tezi, Gazi Üniversitesi, Eğitim Bilimleri Enstitüsü, Ankara.

Scammacca, N., Roberts, G., Vaughn, S., Edmonds, M., Wexler, J., Reutebuch, C., ...Torgesen, J. (2007). Reading interventions for adolescent struggling readers: A meata-analysis with implications for practice. Portsmouth, NH: RMC Research Corporation.

Sencibaugh, J. (2007). Meta-Analysis of reading comprehension interventions for students with learning disabilities: Strategies and implications. Reading Improvement, 44(1), 6-22.

Someren, M. W., Barnard, R., \& Sandberg J. (1994). The think aloud method: A practical guide to modelling cognitive processes. Academic Press, London, UK.

Stetter, M. E., \& Hughes, M. T. (2011). Computer assisted instruction to promote comprehension in students with learning disabilities. International Journal of Special Education, 26(1), 88-100.

Swanson, P. N., \& De La Paz, S. (1998). Teaching effective comprehension strategies to students with learning and reading disabilities. Intervention in School and Clinic, 33 209-218.

Swanson, E. A., \& Vaughn, S. (2010). An observation study of reading instruction provided to elementary students with learning disabilities in the resource room. Psychology in the Schools, 47, 481-492.

Sze, S. (2010). Teaching reading to students with learning difficulties. Reading Improvement, 3(47), 142-152.

Talbott, E., Lloyd, J. W., \& Tankersley, M. (1994). Effects of reading comprehension interventions for students with learning disabilities. Learning Disability Quarterly, 17, 223-232.

Uçar-Rasmussen, M. \& Cora-İnce, N. (2017). Özel öğrenme güçlüğü olan bireylere üstbilişsel okuduğunu anlama stratejilerinin öğretiminde sesli düşünme yönteminin etkililiği. Abant İzzet Baysal Üniversitesi Eğitim Fakültesi Dergisi, 17(4), 2180-2201.

Van Den Broek, P., \& Espin, C. A. (2012). Connecting cognitive theory and assessment: Measuring individual differences in reading comprehension. School Psychology Review, 41, 315-325.

Van den Haak, M. J., Jong de, M. D. T., \& Schellens, P. J. (2003) Retrospective vs. concurrent think-aloud protocols: Testing the usability of an online library catalogue. Behav. Inform. Tech. 22(5), 339-351.

Van Kraayenoord, C. E., \& Schneider, W. E. (1999). Reading achievement, metacognition, reading self-concept and interest: A study of German students in grades 3 and 4. European Journal of Psychology of Education, 14(3), 305-324.

Vaughn, S., Gersten, R., \& Chard, D. (2000). The underlying message in LD intervention research: Findings from research syntheses. Exceptional Children, 67, 99-114.

Walker, B. J. (2005). Thinking aloud: Struggling readers often require more than a model. The Reading Teacher, 58(7), 688-692.

Wigent, C. (2013). High school readers: A profile of above average readers and readers with learning disabilities reading expository text. Learning and Individual Differences, 25, 134-140. 
Amaç.

Bu amacıma nasıl ulaşırım

(Öğrenci)

(Eğitmen)

İmza

EK-B

3D Strateji Öğretim Kağıdı

\begin{tabular}{|c|c|c|}
\hline \multirow{3}{*}{ Okuma Öncesinde } & Yazarın Amacı & \multirow{3}{*}{ Hakkında Düşün } \\
\hline & Ne Bildiğin & \\
\hline & Ne Öğrenmek İstediğin & \\
\hline \multirow{3}{*}{ Okuma Sırasında } & Okuma Hızın & \multirow{3}{*}{ Hakkında Düşün } \\
\hline & Okudukların ile Önceki Bilgilerinin Benzerlik ve Farklııkları & \\
\hline & Anlamadığın ve Tekrar Okuman Gereken Bölümler & \\
\hline \multirow{3}{*}{ Okuma Sonrasında } & Ana Fikir & \multirow{3}{*}{ Hakkında Düşün } \\
\hline & Özet Bilgiler & \\
\hline & Ne Öğrendiğin & \\
\hline
\end{tabular}

EK-C

1) Okumaya Başlamadan Önce:

3D Kontrol Listesi

\begin{tabular}{|c|c|}
\hline & \\
\hline \multicolumn{2}{|c|}{ Yazarın amacı hakkında düşündüm. } \\
\hline a) & Metnin başlığını okudum. \\
\hline b) & Metnin ilk cümlesini veya ilk paragrafını okudum. \\
\hline \multicolumn{2}{|c|}{ Metinle ilgili ne bildiğim hakkında düşündüm. } \\
\hline Metinde & 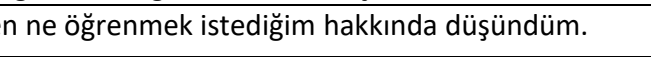 \\
\hline
\end{tabular}

2) Okuma Sırasında:

EVET HAYIR

\begin{tabular}{|l|l|l|}
\hline Okuma hızımın uygun olup olmadığı hakkında düşündüm. & & \\
\hline Önemli gördüğüm yerlerin altını kalemle çizdim. & & \\
\hline Metinde okuduğum bilgiler ile önceki bilgilerim arasındaki benzerlik ve farklııklar hakkında düşündüm. & & \\
\hline Anlamadığım ve tekrar okumam gereken bölümler hakkında düşündüm. & & \\
\hline
\end{tabular}

3) Okuma Sonrasında

\begin{tabular}{|l|c|c|}
\hline \multicolumn{1}{l}{ EVET } & HAYIR \\
\hline Metnin ana fikri hakkında düşündüm. & & \\
\hline Metindeki özet bilgiler hakkında düşündüm. & & \\
\hline Metinden ne öğrendiğim hakkında düşündüm. & & \\
\hline
\end{tabular}


EK -D

3D ROKETLERI

Öğrencinin Adı Soyadı:

Tarih:

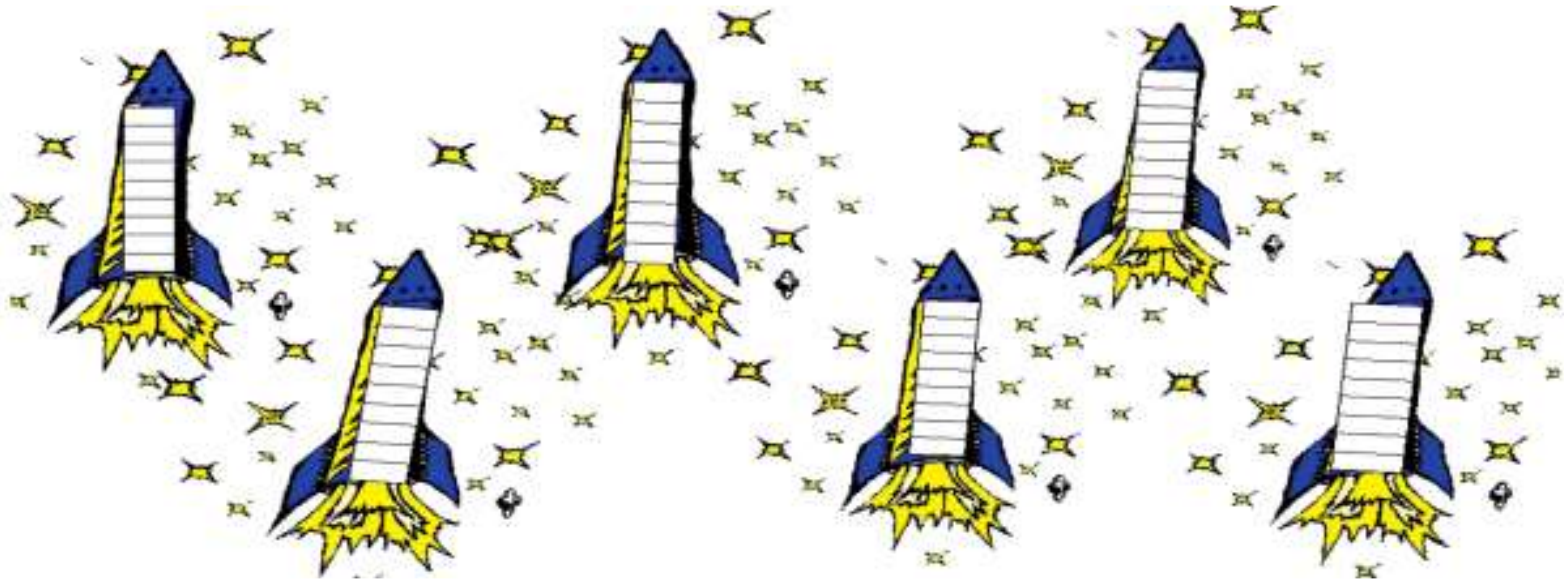

EK-E

3D GÖRSELI

\section{Okuma Öncesinde}

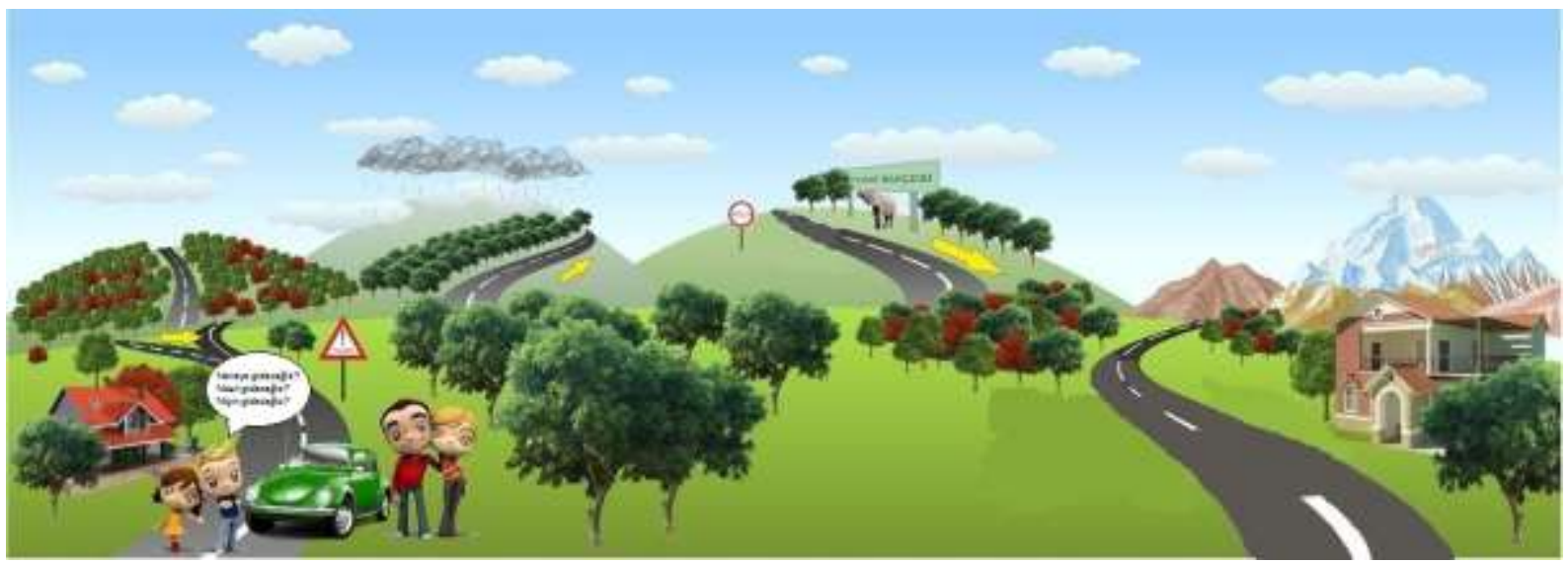

\section{Okuma Sırasında}






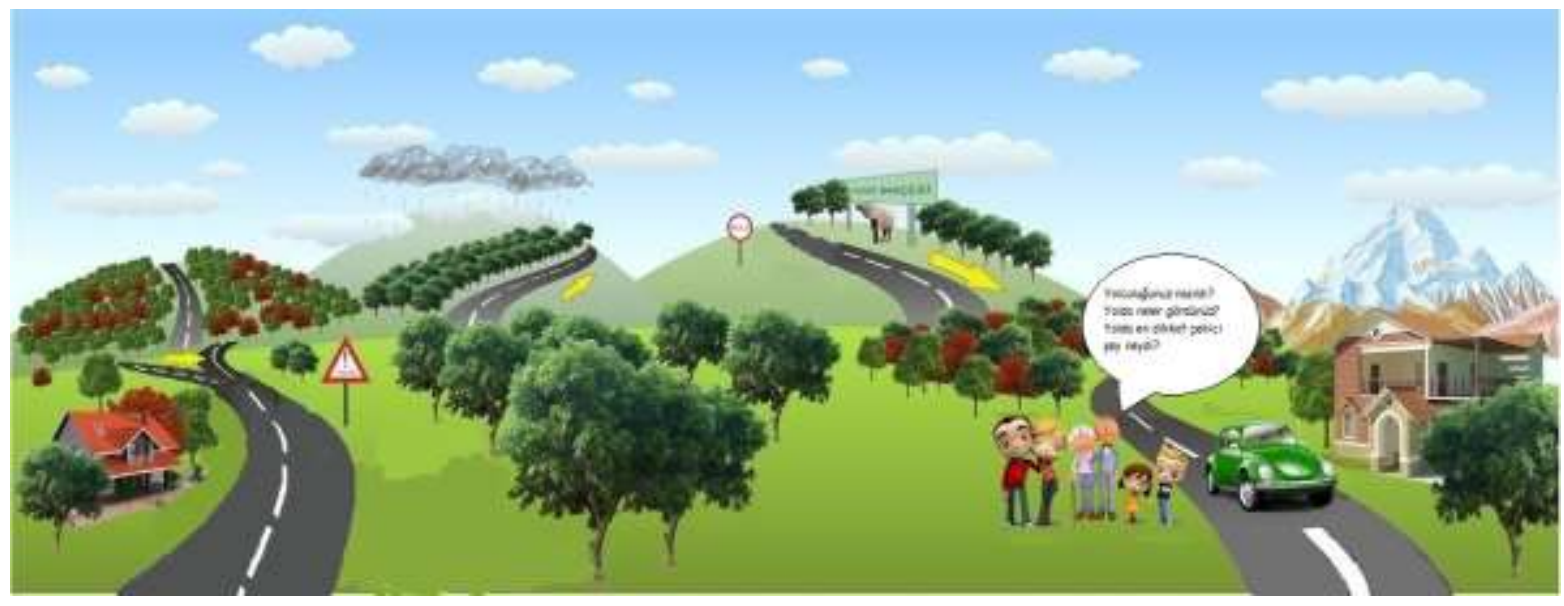

